\title{
践 New Disease Reports \\ First report of Neofabraea kienholzii causing bull's eye rot of apple in the UK
}

\author{
J. Kingsnorth, J. Perrine, A. Berrie and R. Saville*
}

NIAB EMR, New Road, East Malling, Kent ME19 6BJ, UK

*E-mail: robert.saville@emr.ac.uk

Received: 20 Sep 2017. Published: 17 Oct 2017. Keywords: apple postharvest rot, Gloeosporium rot,

Apple rot surveys have been conducted since the 1930's in the UK Together they help build a picture of how the rot profile has changed over time. In surveys conducted in the 1930's and the 1960's (Wilkinson, 1954; Preece, 1967), Neofabraea was the dominant causative agent of rot, but losses due to this pathogen became negligible in the 1980's (Berrie, 1989). More recent surveys found a resurgence of this disease in susceptible varieties (including cv. Cox's Orange Pippin) prompting identification of the species of Neofabraea responsible. Total actual losses due to rots have reduced significantly over the surveying period (for example total losses in cv. Cox's Orange Pippin have reduced 10 fold from $26.3 \%$ in the 1930 's to $2.6 \%$ in the 2010's) thanks to advances in storage technologies. Rots attributed to Neofabraea spp. have reduced from nearly $50 \%$ to $15 \%$ in the same period but this still constitutes an economic loss to growers and packers (Saville et al., 2015).

Apple samples that exhibited discreet, circular "cheek" lesions which were light to dark brown, flat or slightly sunken, and firm, were collected from the packhouse during 2013 and 2014 surveys. Samples were returned to the lab and rinsed with sterile water and surface disinfected with $70 \%$ ethanol. Tissue from the leading edge beneath the skin was isolated and placed on potato dextrose agar. Plates were incubated at $20^{\circ} \mathrm{C}$ with a $16 \mathrm{~h}$ photoperiod. Isolates were slow growing producing colonies of varying colour but with colony morphology characteristics typical of Neofabraed species (Fig. 1). DNA was extracted from axenic, single spore derived cultures, $\beta$-tubulin and ITS regions were amplified and sequenced. BLAST analysis revealed that in addition to $N$. perrenans and $N$. vegabunda isolates, which have been previously reported in the UK (Edney, 1983), a single isolate (G48) out of 49 tested matched Neofabraea kienholzii with $100 \%$ identity. Repeating the above with a collection curated during the 2015 rot survey (growing season 2014), using the more phylogenetically informative $\beta$-tubulin region only, a single isolate (R4/15_2) out of 20 isolates tested had $100 \%$ identity to Neofabraea kienholzii. The sequences have been deposited in GenBank: Accession Nos. MF977989 (G48, ITS), MF983810 (G48, $\beta$-tubulin) and MF983809 (R4/15_2, $\beta$-tubulin).

To prove pathogenicity, Koch's postulates were conducted with isolate G48 (Fig. 2). Apples cv. Cox's Orange Pippin were surface sterilised, wounded with a sterile hypodermic needle and inoculated with $20 \mu \mathrm{l}$ of conidial suspension $\left(3 \times 10^{4}\right.$ conidia $\left.\mathrm{ml}^{-1}\right)$. Inoculation points were coated with petroleum jelly to maintain humidity. After 60 days incubation at $2^{\circ} \mathrm{C}$ simulating commercial storage conditions for cv. Cox's Orange Pippin, lesions had developed on all inoculated apples characteristic of those caused by Neofabraea (Fig. 3). Non-inoculated control fruit showed no symptoms. Isolations from the leading edge of the lesion, as described above, confirmed the presence of Neofabraea.

This is the first report of Neofabraea kienholzii in the UK, where before only $N$. perrenans and $N$. vegabunda isolates were believed to be present (Edney, 1983). Previously named 'Neofabraea sp. nov.', Neofabraea kienholzii was first described by Spotts et al. (2009) and has since been reported in many apple (and pear) growing territories around the world. This data is important to contribute to a global picture of the distribution of this genus and so that control strategies can be tailored for the UK industry to mitigate losses due to apple rot diseases.

\section{References}

Berrie AM, 1989. Storage rots of apple and pear in South East England 1980-88: incidence and fungicide resistance. In: Gessler BK, ed. Integrated Control of Pome Fruit Diseases, IOBC Bulletin 12, 229-239.

Edney KL, 1983. Top fruit. In: Dennis C, ed. Post Harvest Pathology of Fruits and Vegetables. London, UK: Academic Press, 43-71.

Preece TF, 1967. Losses of 'Cox's Orange Pippin' apples during refrigerated storage in England, 1961-65. Plant Pathology , 176-180. http://dx.doi.org/10.1111/j.1365-3059.1967.tb00401.x

Saville RJ, Perrin J, Lower K, Berrie AM, 2015. Sustainable control of postharvest apple rots - from orchard to store. In: den Breeyen A, Gadoury D, Lennox CL, MacHardy WE, Meitz-Hopkins JC, Stensvand A, eds. Integrated Plant Protection in Fruit Crops, Subgroup Pome Fruit Diseases IOBC Bulletin , 169-171

Spotts RA, Seifert KA, Wallis KM, Sugar D, Xiao CL, Serdani M, Henriquez JL, 2009. Description of Cryptosporiopsis kienholzii and species profiles of Neofabraea in major pome fruit growing districts in the Pacific Northwest USA. Mycological Research 113, 1301-1311. http://dx.doi.org/10.1016/j.mycres.2009.08.013

Wilkinson EH, 1954. Fungal rots of apples with special reference to Gloeosporium spp. Annals of Applied Biology 41, 354-358. http://dx.doi.org/10.1111/j.1744-7348.1954.tb01129.x

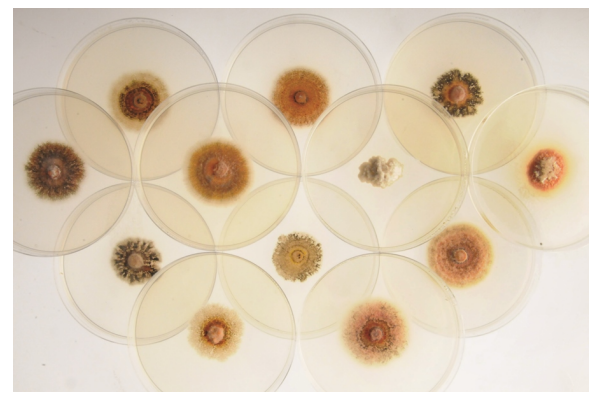

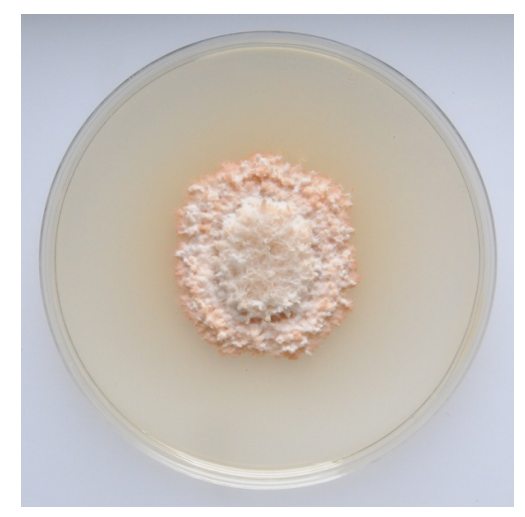

Figure 2

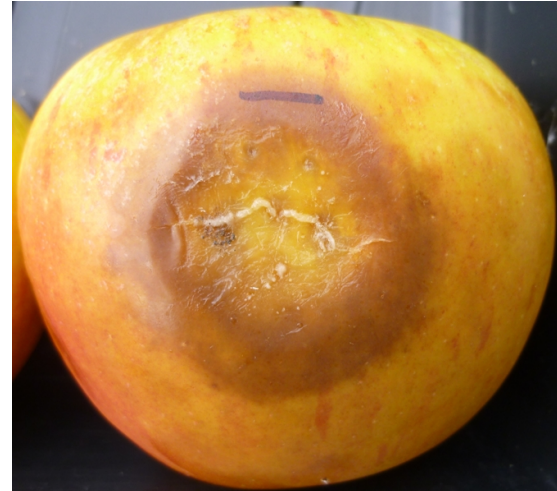

Figure 3

To cite this report: Kingsnorth J, Perrine J, Berrie A, Saville R, 2017. First report of Neofabraea kienholzii causing bull's eye rot of apple in the UK. New Disease Reports 36, 15. http://dx.doi.org/10.5197/j.2044-0588.2017.036.015

C) 2017 The Authors

This report was published on-line at www.ndrs.org.uk where high quality versions of the figures can be found. 